\title{
Investigation of Oxidative Stress Levels of Male Football Players
}

\author{
Yakup Aktaş ${ }^{1}$, Hakim Çelik ${ }^{2}$ \\ ${ }^{1}$ Harran University, School of Physical Education and Sports, Şanlıurfa, Turkey \\ ${ }^{2}$ Harran University, Faculty of Medicine, Department of Physiology, Şanlıurfa, Turkey ${ }^{1}$ \\ Correspondence: Yakup Aktaş, Harran University, School of Physical Education and Sports, Şanlıurfa, Turkey.
}

Received: February 13, 2019

doi:10.11114/jets.v7i8.4329

\author{
Accepted: March 1, 2019 Online Published: June 17, 2019 \\ URL: https://doi.org/10.11114/jets.v7i8.4329
}

\begin{abstract}
Introduction and Aim: While severe acute exercise increases the production of free radicals in skeletal muscles, regular and continuous exercise strengthens the antioxidant defence mechanism. Consequently, it was aimed to compare the oxidative stress levels of the male football players who regularly train in our study with the healthy control group who do not exercise regularly and to evaluate the effect of doing regular football training on the oxidant-antioxidant system.
\end{abstract}

Material and Method: A total of 59 people consisting of 29 football players of 11 Nisan Football Club in Turkey Football Federation Regional Amateur League (BAL) who train regularly and 30 healthy and volunteer control group who are students at Harran University, Faculty of Medicine and whose ages and body mass index are similar to the each other participated in the study. Total Oxidant Level (TOS), Total Antioxidant Level (TAS), Advanced Protein Oxidation Products (AOPP) and Oxidative Stress Indexes (OSI) of the participants were studied. Mann-Whitney U test and Student-t Test were used for data analysis and $\mathrm{p}<0.05$ was considered significant.

Findings: At the end of the study, no statistically significant difference was observed in the TOS, TAS, AOPP and OSI levels between the football players who train regularly and the sedentary group ( $p>0,01)$. However, TOS, OSI and AOPP values were found to be lower in favour of football players while TAS values are high in favour of football players.

Consequently; although the acute exercise in the literature increases oxidative stress, it is obvious that a healthy life and physical activity is necessary to avoid from chronic diseases. As a result of our study, it is observed that when exercises are performed in long-term, regularly and at appropriate intensities they strengthen the antioxidant defence system that suppresses oxidative stress.

Keywords: football, antioxidant, oxidative stress

\section{Introduction}

Oxidative stress is the slipping of the balance in oxidative metabolism to the oxidative direction as a result of increase of oxidant level in the body and / or the decrease in the antioxidant level. In particular, free radicals that affect DNA cause irreversible damage to the organism (Dadheech et al. 2008). It is stated that free radicals may be responsible for mutation, cellular damage, aging and cancer (Harman, 1981, Aikawa et al., 1997).

Antioxidants are defined as substances that prevent the progression of autoxidation / peroxidation by reacting rapidly with radicals. The speed of formation of free radicals in the organism and their speed of elimination are in equilibrium and this situation is called oxidative equilibrium. As long as this balance is achieved, the organism is not affected by free radicals. A decrease in the level of increase or elimination of the radicals at the level of formation causes this balance to deteriorate. This condition, also called as 'oxidative stress', shows the imbalance between the formation of free radicals and antioxidant mechanism and causes tissue damage (Serafini and Del Rio, 2004).

AOPP, called as Advanced Oxidation Protein Products in 1996, increases in value as a marker showing the effect of oxidative stress on proteins (Witko-Sarsat et al., 1996).

Proteins are susceptible to free radical damage. The effects of free radicals also include oxidative modification of proteins. Therefore, plasma AOPP level is a useful marker for protein oxidative damage (Matteucci et al., 2001).

Energy is necessary for physical activity. As exercise intensity increases, the amount of energy needed also increases 
(Kalyon, 1997). Due to the increase in muscle activity, energy production and consumption, blood flow to the muscle working and need for oxygen increase significantly (Akgün 1994; Taşkıran, 1997).

The use of oxygen in skeletal muscles may increase by 100-200 times in a severe exercise (Ohno et al., 1993; Sjogaard, 1990). Correspondingly, it is thought that lipid peroxidation occurs if the increase in the level of free oxygen radicals during exercise surpasses the antioxidant level. The damage occurred in the body affects the regeneration time in athletes. However, it is reported that regular chronic exercises reduce oxidative stress, increase antioxidant defence, and increase the level of antioxidants (Radak et al., 1999; Leeuwenburgh and Heinecke, 2001; Jamurtas, 2003; Cazzola et al., 2003; Banfi et al., 2005, Düzova et al., 2006; Fıçıcılar et al., 2006; Güllü, 2007; Kıyıcı and Kishalı, 2010; Kürkçü et al., 2012).

In this study, it is aimed to investigate the oxidant and antioxidant levels in the body caused by chronic exercise in male football players.

\section{Material and Method}

\subsection{Participants}

A total of 59 people consisting of 29 football players of 11 Nisan Football Club in Turkey Football Federation Regional Amateur League (BAL) who train regularly for two hours a day, five days a week for five years at least and 30 volunteers who are students at Harran University, Faculty of Medicine who are not interested in any kind of sports regularly participated in the study.

Age, height and body weights of the participants are given in Table 1.

Table 1. Age, height and body weights of the participants

\begin{tabular}{lll}
\hline Parameters & Football Player $(\boldsymbol{n = 2 9})$ & Control $(\boldsymbol{n}=\mathbf{3 0})$ \\
& $\mathbf{X} \pm \mathbf{S s}$ & $\mathbf{X} \pm \mathbf{S s}$ \\
Age $($ years $)$ & $21,6667 \pm 2,74$ & $21,2333 \pm 1,19$ \\
Height $(\mathbf{c m})$ & $1,7713 \pm 0,06$ & $1,7673 \pm, 005$ \\
Weight $(\mathbf{k g})$ & $70,0413 \pm 7,66$ & $72,6133 \pm 11,38$ \\
\hline
\end{tabular}

\subsection{Collecting Blood Samples}

The fasting venous resting blood samples of the participant were taken (after at least 6 hours fasting). The blood samples taken were put in centrifugal machine at $1500 \mathrm{rpm}$ for 15 minutes and the serum samples obtained were kept at $-80^{\circ} \mathrm{C}$ until the consumables and kits required for the study were procured.

\subsection{Biochemical Analysis}

Total Oxidant Level (TOS), Total Antioxidant Level (TAS), Oxidative stress index OSI and Advanced Protein Oxidation Level (AOPP) concentrations in the serums obtained were analysed by ELIZA method in Thermo Scientific Varioskan Lux device in Harran University Faculty of Medicine Physiology Laboratory.

Total Oxidant Level (TOS): total antioxidant concentration of the samples (TAS)was analyzed by implementing the procedure in Rel Assay branded commercial kits (Rel Assay Kit Diagnostics, Turkey) developed by (Erel, 2005).

Total Antioxidant Status (TAS): total antioxidant concentration of the samples (TAS) was analyzed by implementing the procedure in Rel Assay branded commercial kits (Rel Assay Kit Diagnostics, Turkey) developed by EREL.

Advanced Protein Oxidation Level (AOPP): Advanced Protein Oxidation Level (AOPP) was analyzed by implementing the procedure in Rel Assay branded commercial kits (Rel Assay Kit Diagnostics, Turkey) developed by EREL.

Oxidative Stress Index (OSI): After the TAS and TOS intensities were converted to the same units, OSI stated as the the percentage of the proportion of TOS levels to TAS levels (Erel 2005), was calculated. In calculation, OSI $=(\mathrm{TOS}, \mu \mathrm{mol}$ $\mathrm{H} 2 \mathrm{O} 2$ equiv./lt) $\div$ (TAS, mmol Trolox equiv./lt X 10 formula) was used. The calculation result was expressed in AU (Arbitrary Unit). All the blood analyses were studied in Harran University Faculty of Medicine Physiology Laboratory.

\subsection{Statistical Analysis}

Comparisons between the experimental and control groups were performed by using the Mann-Whitney $U$ test in independent groups in SPSS 23, as the number of cases was less than thirty and the data were not normally distributed. $\mathrm{P}<0.05$ was considered significant.

This study was approved by the Ethics Committee of the Health Sciences, the Rectorate of Harran University on 16.11.2018 with the decision No. 2011.5.1 / 2 in terms of ethical rules. 


\section{Findings}

Table 2. Relationship between TOS, AOPP, OSI and TAS values of Football Players and sedentary group

\begin{tabular}{lccc}
\hline Parameters & Footballers $(\boldsymbol{n}=\mathbf{2 9})$ & Control $(\boldsymbol{n}=\mathbf{3 0})$ & $\boldsymbol{p}$ \\
& $\mathbf{X} \pm \mathbf{S s}$ & $\mathbf{X} \pm \mathbf{S s}$ & \\
\hline TAS $(\mathbf{m m o l}$ Trolox Equiv/L) & $1,29 \pm 0,41$ & $1,28 \pm 0,36$ & 0,873 \\
TOS $(\boldsymbol{\mu m o l ~ H 2 O 2 ~ E q u i v / L ) ~}$ & $5,86 \pm 4,4$ & $6,07 \pm 4,5$ & 0,072 \\
AOPP $(\boldsymbol{\mu m o l} / \mathbf{L})$ & $27,13 \pm 17,66$ & $27,73 \pm 16,43$ & 0,893 \\
OSİ $(\mathbf{A U})$ & $4,49 \pm 2,4$ & $5,19 \pm 3,01$ & 0,448 \\
\hline
\end{tabular}

$(\mathbf{p}<\mathbf{0 . 0 5})$

Table 2 shows that although there was no statistically significant relationship between the TAS values of groups who perform regular football training and the sedentary group $(\mathrm{p}<0.05)$, the values were higher numerically in favour of football players. There was no statistically significant relationship between TOS, AOPP and OSI values of football players and sedentary group ( $\mathrm{p}<0.05$ ), but TOS, AOPP and OSI values were lower in favour of football players.

\section{Discussion and Conclusion}

This study was carried out to determine the effects of regular and long-term training on (TOS), which is an indicator of oxidative stress in football players, (TAS), which is an indicator of antioxidant, oxidative stress index (OSI), which is a proportion of TOS and TAS values and advanced protein oxidation, which is an indicator of oxidant-mediated protein damage on AOPP.

In the literature, the number of studies examining TOS changes during chronic exercises is relatively low.

Scientific studies state that acute intense exercise increases oxidative stress. Total oxidant level (TOS) is one of the criteria that shows that oxidative stress level increases in the body (Thirumalai et al., 2011; Wiecek et al. 2015).

The results of the research conducted on humans and experimental animals showed that the TOS values that are one of the indicators of oxidative stress were significantly higher with exercise (Radak et al., 1995; Ramel et al., 2004; Özçelik and Karataş, 2008; Thirumalai et al., 2011; Kürkçü, Çakmak and Zeyrek, 2012). Contrary to these studies, in some studies, it is stated that acute exercises do not have an effect on oxidative stress or decrease oxidative stress (Cooper et al., 2002; Düzova et al., 2006; Aksu et al., 2009; Kıyıcı and Kishalı, 2010; Sarıtaş et al. , 2011).

In the studies of Ağırbaş et al. (2015), when the TOS values of the sedentary and the exercise group were compared, it can be seen that there were statistically significant differences between the groups in favour of the exercise group. In the studies of Vollaard et al. (2005), they reported based upon the results from the studies conducted and the results obtained from sedentary participants and trained participants that the chronic exercise does not change the level of TOS and it is seen that this result supports our study. In our study, there was no statistically significant difference in the TOS values of football players and sedentary group and the values of football players were found to be lower.

In the studies conducted, it is seen that oxidative stress increases together with acute exercise. In addition to this, there are also some studies in which the level of antioxidants increase with chronic exercise. We can see the destructive effect and constructive effect left in organism by exercise thanks to the oxidative stress index OSI that is the ratio of TOS and TAS values. In the studies conducted by Kürkçü et al. (2012), it is seen that there were statistically significant values in favour of taekwondo athletes when we look at the OSI values of taekwondo athletes and control group.

In this study, when we look at OSI values of football players and sedentary group, we can see that the values are lower in favour of football players although there was no statistically significant relationship between groups.

There are also some studies reporting that antioxidant protection system decreases immediately temporarily following acute exercise. Because antioxidants are used to neutralize free radicals produced during exercise (Teixeira et al. 2013). However, studies showing that the level of TAS has increased are also available in the literature (Zalavras et al. 2015).

It was reported that regular chronic endurance and resistance exercises reduce oxidative stress, strengthen antioxidant defence, and increase antioxidant level (Leaf et al., 1997; Turgut et al., 1999; Radak et al., 1999; Schröder et al. 2000; Leeuwenburgh and Heinecke. Et al., 2003; Banif et al., 2005, Düzova et al., 2006; Ficcilar et al., 2006; Güllü, 2007; Kiyici and Kishali, 2010; 2012).

There are also some studies showing that acute or short-term exercises cause decreases in the levels of antioxidants (Thirumalai et al., 2011, Sarıtaş et al., 2011).

Inal et al. (2001) found that long and short distance swimming exercises increases antioxidant enzyme activities. 
In the study of Ağırbaş et al. (2015), it was seen in their study conducted on 18 male rats that when TAS values of sedentary and exercise groups were compared, there were not statistically significant difference between the groups, but the values of the exercise group was found to be quite high.

In our study, although there was no statistically significant relationship between the TAS values of football players and sedentary group, it was found higher in favour of the football players.

When the literature was investigated, it was seen that chronic exercises improved the antioxidant defence system in direct proportion to exercise duration and these results supported our research.

Advanced oxidation protein products (AOPP) are an indicator of oxidant-mediated protein damage. There are also few studies investigating the relationship between exercise and AOPP in humans.

Şinoforoğlu et al. (2006) determined in football players who train regularly that the AOOP value of exercise causing acute fatigue was $291,28 \pm 75,33 \mu \mathrm{mol} / \mathrm{L}$ before the exercise and $328,74 \pm 151,98 \mu \mathrm{mol} / \mathrm{L}$ after the exercise. However, when the change in AOPP values were examined statistically, they could not find a statistically significant difference between the values ( $p>0.05)$.

In the study, AOPP values between footballers and sedentary group were not statistically different, but the AOPP values of the football players were found to be lower numerically.

Consequently; although the acute exercise in the literature increases oxidative stress, it is obvious that physical activity is necessary for a healthy life and to avoid from chronic diseases. As a result of our study, it is seen that the exercises strengthen the antioxidant defence system which suppresses oxidative stress in case of long term, regular and appropriate intensities.

\section{References}

Ağırbaş, Ö., Kishalı, N. F., \& Kıyıcı, F. (2015). Yoğun Egzersizle Oluşan Oksidatif Stres ve DNA Hasarı Üzerine Askorbik Asidin Etkisi, Ankara Üniversitesi Spor Bil Fak., 13(1), 65-72. https://doi.org/10.1501/Sporm_0000000270

Aikawa, R., Komuro, I., Yamazaki, T., Zou, Y., Kudoh, S., Tanaka, M., ... Yazaki, Y. (1997). Oxidative stres activates extracellular signal regulated kinases through Srcand Ras in cultured cardiac myocytes of neonatal rats. J. Clin Invest., 100(7), 1813-1821. https://doi.org/10.1172/JCI119709

Akgün, N. (1994). Egzersiz Fizyolojisi, Ege Üniversitesi Yayınları, s.25-45, İzmir.

Aksu, İ., Topcu, A., Çamsari, U. M., \& Acikgöz, O. (2009). Effect of acute and chronic exercise on oxidant-antioxidant equilibrium in rat hippocampus, pref-rontal cortex and striatum. Neuroscience Letters, 452, 281-285. https://doi.org/10.1016/j.neulet.2008.09.029

Banfi, G., Malavazos, A., \& Iorio, E. et al. (2005). Plasma Oxidative Stress Biomarkers, nitricoxideand heat shock protein 70 in trained elite soccerplayers. Eur J ApplPhysiol; 5,483-486. https://doi.org/10.1007/s00421-005-0104-6

Cazzola, R., Russo-Volpe, S., Cervato, G., \& Cestaro, B. (2003). Biochemical assessments of oxidative stress, erythrocyte membrane fluidity and antioxidant status in professional soccer players and sedentary controls. Eur $J$ Clin Invest., 33, 924-30. https://doi.org/10.1046/j.1365-2362.2003.01227.x

Cooper, C. E., Vollaard, N. B. J., \& Choueiri, T. et al (2002). Exercise, free radicals and oxidative stress. Bioc-hemical Society Transactions, 30, 280-285. https://doi.org/10.1042/bst0300280

Dadheech, G., Mishra, S., Gautam, S., \& Sharma, P. (2008). Evaluation of antioxidant deficit in schizophrenia. Indian J Psychiatry, 50(1), 16-20. https://doi.org/10.4103/0019-5545.39753

Del Rio, D., Serafini, M., \& Pellegrini, N. (2002). Selected Methodologies to assess oxidative/antioxidant status in vivo: a critical review. Nutr Metab Cardiovasc Dis., 12, 343-351.

Düzova, H., Emre, M. H., \& Karakoç, Y. et al. (2006). Orta ve yüksek düzeyde treadmill egzersizinin sıçanların kas ve eritrosit oksidan/antioksidan sistemine etkisi, Journal of Inonu University Medical Faculty, 13, 15.

Erel, O. (2005). A new automated colorimetric method for measuring total oxidant status. Clin Biochem., 38(12), 1103-1111. https://doi.org/10.1016/j.clinbiochem.2005.08.008

Fiçıcılar, H., Zergeroğlu, A. M., \& Ersöz, G. (2006). The effects of short-term training on plateletfuncti-ons and total antioxidant capacity in rats. Physiolo-gical Research/Academia Scientiarum Bohemos-lovaca, 55, 151-156.

Güllü, E. (2007). Sedanterlerde ve Dayanıklılık Sporcularında Maksimal ve Submaksimal Egzersiz Sonrası Oluşan Oksidan Stres ve Antioksidan Düzeylerinin Karşılaştırılması. Gazi Üniversitesi Sağlık Bilimleri Enstitüsü, Beden Eğitimi ve Spor Anabilim Dalı. Doktora Tezi, Ankara. 
Harman, D. (1981). The aging process. Proc Nath Acad Sci USA; 78(11), 7124-7128. https://doi.org/10.1073/pnas.78.11.7124

Inal, M., Akyüz, F., Turgut, A., \& Getsfrid, W. M. (2001). Effect of aerobic and anaero-bic metabolism on free radical generation swimmers. Med Sci Sports Exerc., 33, 564-567. https://doi.org/10.1097/00005768-200104000-00009

Jamurtas, A. Z., Fatouros, I. G., \& Deliconstatinos, G. et al. (2003). Chronic endurance and resistance exercise effects on oxidative stress and antioxidant status of inactive older adults, Medicine \& Science in Sports \& Exercise, 35(5), p-96. https://doi.org/10.1097/00005768-200305001-00533

Kalyon, T. A. (1997). Spor Hekimliği Sporcu Sağlığı ve Spor Sakatlıkları, 4. Baskı, Ankara.

Kıyıcı, F., \& Kishalı, N. F. (2010). Alp Disiplini kayakçılarında sürat egzersizleri sonrası kan antioksidan düzeylerinin incelenmesi, Atatürk Üniversitesi Beden Eğitimi ve Spor Bilimleri Dergisi (ATABESBD), 12, 1-9.

Kürkçü, R., Çakmak, A., \& Zeyrek, D. (2012). Taekwondo antrenmanlarının çocuklarda oksidatif stres üzerine etkisi, Erciyes Tip Dergisi/Erciyes Medical Journal, 34:7-9. https://doi.org/10.5152/etd.2012.02

Leaf, D. A. (1997). The effect of Exercise İntensity on Lipid Peroxidation. Med. Sci. Sports Exerc., 29(8), 1106-1109. https://doi.org/10.1097/00005768-199708000-00008

Leeuwenburgh, C., \& Heinecke, J. W. (2001). Oxidative stress and antioxidants in exercise. Current Medicinal Chemistry, 8, 829-838. https://doi.org/10.2174/0929867013372896

Matteucci, E., Biasci, E., \& Giampietro, O. (2001). Advanced oxidation protein products in plasma: stability during storage and correlation with other clinical characteristics. Acta Diabetol; 38, 187-189. https://doi.org/10.1007/s592-001-8077-3

Ohno, H., Kayashima, S., Nagata, N., Yamashiya, H., Ookawara, T., \& Taniguchi, N. (1993). Changes in immunoreactive manganese-superoxide dismutase concentration in human serum after $93 \mathrm{~h}$ strenuous physical exercise. Clinica Chimica Acta, 215, 213-219. https://doi.org/10.1016/0009-8981(93)90127-P

Özçelik, O., \& Karataş, F. (2008). Şiddeti Düzenli Olarak Artan İşe Karşı Yapılan Egzersizin Obezlerde Serum Malondialdehid ve Vitamin A, E, C Düzeyleri Üzerine Olan Etkisi. Fırat Üniversitesi Sağllk Bilimleri Dergisi (FUSABIL), 22, 337-341.

Radák, Z., Asano, K., Inoue, M., Kizaki, T., Oh-Ishi, S., Suzuki, K., Taniguchi, N., \& Ohno, H. (1995). Superoxide dismutase derivative reduces oxidative damage in skeletal muscle of rats during exhaustive exercise. J. Appl. Physiol., 79, 129-135. https://doi.org/10.1152/jappl.1995.79.1.129

Radak, Z., Kaneko, T., \& Tahara, S., et al (1999). The effect of exercise training on oxidative damage of lipids, proteins and DNA in rat skeletal muscle: evidence for beneficial outcomes. Free Radical Biology and Medicine, 27, 69-74. https://doi.org/10.1016/S0891-5849(99)00038-6

Ramel, A., Wagner, K. H., \& Elmadfa, I. (2004). Plasma antioxidants and lipid oxidation after submaximal resistance exercise in men, Eur. J. Nutr., 43, 2-6. https://doi.org/10.1007/s00394-004-0432-z

Sarıtaş, N., Uyanık, F., \& Hamucu, Z. (2011). Effects of acute twelve two minute run test on oxida-tive stress and antioxidant enzyme activities. African Journal of Pharmacy and Pharmacology, 5, 1218-1222. https://doi.org/10.5897/AJPP11.263

Schröder, H., Navarro, E., Tramullas, A., Mora, J., \& Galiano, D. (2000). Nutrition Antioxidant Status and Oxidative Stress in Professional Basketboll Players: Effects of a three Compound Antioxidative supplement. Int. J. Sports Med., 21, 146-150. https://doi.org/10.1055/s-2000-8870

Serafini, M., \& Del Rio, D. (2004). Understanding the association between dietary antioksidants, redoks status and disease: is the total antioksidant capacity the right tool? Redoks Report, 9, 145-15. https://doi.org/10.1179/135100004225004814

Şinoforoğlu, T., Özel, Ü., Kiliç, N., \& Sevim, Y. (2006). Akut Egzersizin Futbolcularda Oksidatif Stres Üzerine Etkisi, 9. Uluslararası Spor Bilimleri Kongresi, Muğla, Türkiye, 3-5 Kasım, 413-416.

Sjogaard, G. (1990). Exercise-induced muscle fatique: The significance of potassium. Acta Physiol Scand Suppl, 593, $15-44$.

Taşkıran, D., Kutay, F. Z., Sözmen, E. Y., \& Pöğün, Ş. (1997). Sex Differences in Nitrid-Nitrat Levels and Antioxidant Defence in Rat Brain. Neuroreport, 8(4), 881-84. https://doi.org/10.1097/00001756-199703030-00013

Teixeira, V. H., Valente, H. F., Casal, S. I., Marques, F. P., \& Moreira, P. A. (2013). Blood antioxidant and oxidative stress biomarkers acuteresponses to a 1000-m kayak sprint in elite male kayakers. J Sports Med Phys Fitness, 53, 
71-79.

Thirumalai, T. V., Therasa, S., \& Elumalai, E. K. et al (2011). Intense and exhaustive exercise induce oxidative stress in skeletal muscle, Asian Pacific Journal of Tropical Disease, 63-66. https://doi.org/10.1016/S2222-1808(11)60016-9

Turgut, A., Özgürbüz, C., Azboy, O., Akyüz, F., İnal, M., Göktürk, E., \& Seber, S. (1999). Yüzücülerde Aerobik ve Anaerobik Ağırlıklı Yüklenmelerde Oksidatif Stresin Karşılaştırılması. Spor Hekimliği Dergisi, 34, 1-10.

Vollaard, N. B., Shearman, J. P., \& Cooper, C. E. (2005). Exercise-induced oxidative stress: myths, realities and physiological relevance. Sports Med., 35, 1045-1062. https://doi.org/10.2165/00007256-200535120-00004

Wiecek, M., Maciejczyk, M., Szymura, J., \& Szygula, Z. (2015). Changes inoxidative stressand acid-base balance in men and women following maximal-intensity physical exercise. Physiol. Res., 64, 93-102.

Witko-Sarsat, V., Friendlander, M., \& Capeillere-Blandin, C. (1996). Advanced oxidation protein products as a novel marker of oxidative stress in uremia. Kidney Int., 49, 1304-1313. https://doi.org/10.1038/ki.1996.186

Zalavras, A., Fatouros, I. G., \& Deli, C. K. et al. (2015). Age related responses in circulating markers of redox status in healthy adolescents and adults during the course of a training macrocycle. Oxid Med Cell Longev; $2015,283921$. https://doi.org/10.1155/2015/283921

\section{Copyrights}

Copyright for this article is retained by the author(s), with first publication rights granted to the journal.

This is an open-access article distributed under the terms and conditions of the Creative Commons Attribution license which permits unrestricted use, distribution, and reproduction in any medium, provided the original work is properly cited. 